811.111'276.6:55

811.163.41'276.6:55

378.147::811.111

https://doi.org/10.18485/sj.2019.24.1.41

ЛИДИЈА В. БЕКО

Универзитет у Београду

Рударско-геолошки факултет
Оригинални научни рад

Примљен: 09. 10. 2018.

Прихваћен: 15. 01. 2019.

\title{
ПОДУЧАВАњЕ РУДАРСКЕ ТЕРМИНОЛОГИЈЕ НА РГФ-У ПУТЕМ CLIL МЕТОДЕ И СРПСКОГ ЈЕЗИКА НА ПРВОЈ ГОДИНИ СТУДИЈА
}

\begin{abstract}
Рад полази од става да се увођење CLIL методе на РГФ-у намеће као корисно и неопходно у оној мери у којој се данас пословање, комуникација, наука и истраживање чврсто повезују са страним језиком, или прецизније са енглеским језиком (EJ $)^{1}$. У иницијаланој намери да CLIL методу уведемо на РГФ на одржив начин, сматрали смо нужним да нашим студентима олакшамо подучавање рударске терминологије уз помоћ српског језика (CJ) како бисмо им већ од прве године студија помогли да формирају квалитетну лингвистичку основу која би убудуће могла да подржи сваки даљи садржински, когнитивни, културни и комуникативни развој. Полазећи од овог оквира, ураду се бавимо: прво, карактеристикама CLIL методе и препорукама у подучавању и учењу вокабулара; друго, сложеном рударском терминологијом и како се она преводи, и треће, значајем смисленог коришћења СЈ и његове улоге у интегрисаној настави. У наставку рада понудили смо емпиријско истраживање које анализира перцепцију студената о понуђеном моделу учења, док у финалном делу, рад даје позитивну аргументацију
\end{abstract}

*lidija.beko@rgf.bg.ac.rs

${ }^{1}$ Корисно би било напоменути да иако прво „L” (језик) у оквиру $C L I L$ акронима треба да означава било који страни језик, у стварности превласт коју има енглески је огромна у односу на малу групу других престижних језика, па је стога необјективно порицати његову доминацију (Фернандез и др. 2008) 
о сврсисходности употребе СЈ и изражава повољан став о ефикасности понуђене стратегије учења рударске терминологије под окриљем CLIL методе.

Кључне речи: $C L I L$ метода, подучавање вокабулара, рударска терминологија, ЕJ, CJ

\section{1. УВОД}

Како би се под окриљем Болоњског процеса високо образовање стандардизовало и отворило за тржиште европских и ваневропских студената, приступило се усаглашавању наставних програма, придруживању бодовног система, повећању транспарентности наставних материјала као и еквиваленцији диплома. Најочигледнијом последицом Болоњског процеса, међутим, ипак би се могла сматрати „англиканизација” или „инглишизација” наставе (Колман 2006: 1), приликом које се као радни језик на академским студијама све више користи енглески. Оваквим језичким поступком остварују се предуслови за следеће крупније циљеве: подстиче се већа академска сарадња у оквиру европских, а затим и светских универзитета, унапређује се професорска и студентска мобилност, привлаче се међународни студенти, подиже се репутација кадра, унификују курикулуми и силабуси који у таквом заједничком језичком простору постају прихватљиви за све учеснике подједнако (Вехтер 2008).

Међутим, унутар овог подручја интернационализације, у коме је енглески примарни медиј и подразумева висок ниво знања језика, постоји велики број билингвалних или двојезичних модела у којима се паралелизује учење језика са предметним садржајем међу којима се налази и CLIL. Разлика између билингвалног и интегрисаног приступа јесте та да се код билингвалног приступа настоје остварити лингвистички циљеви, док јециљ CLIL-а постизање когнитивних захтева или остварење академског напретка у предметној области. Уопштено гледано, CLIL описује шири спектар организовања наставе од билингвалног у коме се додатни или страни језик употребљава као радни језик на предавањима чији примарни циљ није језички, то јест где се учење језика креира искључиво према садржају предмета (Марш 2002: 2).

С друге стране, иако је иницијатива интегрисане језичке и доменске наставе намењена развоју страног или радног језика, стручњаци попут Каминса сматрају да „први језик не сме бити напуштен пре него што се у потпуности развије, а да страни језик, у односу на тај процес, треба уводити било симултано било сукцесивно" (Каминс 2000: 25). Употреба матерњег језика, у нашем случају српског, представља драгоцен ресурс и неодвојив је од усвајања страног језика јер би се тиме нарушиле већ успостављене бројне когнитивне, социјалне и емотивне везе (Свеин и др. 2011; Турнбул 2001; Кук 2001). Стога смо сагласни са мишљењем да матерњи језик на почетној години 
имплементације $C L I L-$-а никако не може да представља претњу или препреку у усвајању страног језика, већ само може да се говори о разумном и дозираном коришћењу СJ, примереној датој језичкој ситуацији или говорном догађају (Аткинсон 1993: 2).

\section{2. КАРАКТЕРИСТИКЕ CLIL МЕТОДЕ КРОЗ АСПЕКТ ВОКАБУЛАРА}

У оквиру CLIL наставног програма, као циљ се поставља да више од $50 \%$ предавања буде на додатном језику, а по „тврдој” варијанти (енгл. hard $C L I L)$, предавачи би требало да буду експерти из области садржаја, или да им, у идеалном случају, асистирају изворни говорници циљног језика што је, нажалост, у пракси тешко оствариво. Како би се интегрисана настава на РГФ, према строгим теоретичарима и практичарима $C L I L-$ - могла сматрати прихватљивом, а полазећи од „меке” варијанте (енгл. soft $C L I L)$, определили смо се за Моханову опцију где предавање језика прати предавање садржаја, и где је фокус подељен и на садржај и на језик како би студенти добили неопходно лингивистичко знање потребно за даље учење садржаја (Мохан 1986: 25).

По питању вокабулара, теоријски темељи $C L I L$-а ослањају се на две најзначајније теорије усвајања језика, Крашенове инпут хипотезе или хипотезе праћења (Крашен 1985: 15-22) и Свеинове аутпут хипотехе или хипотезе исхода (Свеин 2000: 31-35, 2006: 54-57). Крашенова инпут хипотеза или модел праћења представља најзначајнију рецептивну теорију усвајања језика и вокабулара, где се као предуслов узима богато, разумљиво и разложно излагање студената језику, што подразумева стварање ситуације које караткеришу позитивне емоције (Крашен 1985: 15).

Прилагођено Крашеновом принципу, CLIL настава у домену вокабулара на РГФ-у је високоиндивидуализована, осетљива на међугенерацијске промене и прилагодљива је динамичном језику струке. Стога се она на иницијалној фази изводи применом следећих принципа:

1. Процес усвајања језика кроз вокабулар пре свега треба да покрене студенте да се померају на линији самокритичног уочавања празнина у ономе што не знају или оном што делимично знају;

2. Учење вокабулара је ситуирано у доменски контекст;

3. Учење уз помоћ CLIL методе пружа могућност да се динамично и прецизно развије свест о смислу (рецепција), свим значењима (превод), могућностима употребе (продукција);

4. Тандемски рад доменског и језичког професора представља додатни стуб квалитетног подучавања стручног вокабулара; и 
5. Активности вежбање вокабулара у CLIL настави оспособљавају студента да стиче аутономију и повећавају језичку компетенцију из области стручне терминологије.

\title{
3. ПОТРЕБА ЗА КОРИШЋЕЬЕМ СЈ КАО ЛИНГВИСТИЧКОГ PECУPCA
}

\begin{abstract}
Употреба матерњег језика обезбеђује осећај сигурности и лингвистички дефинише проживљено искуство, омогућавајући студенту да се адекватно изрази. Студент је тада спреман да експериментише и ризикује у погледу употребе страног језика (Ауербах 1993: 25).
\end{abstract}

Из наведеног цитата јасно је да матерњи језик представља зону језичке сигурности за сваког говорника што, по мишљењу Ауербаха, представља и природни предуслов за психолошку сигурност при усвајању страног језика и вокабулара. Сличан став имају и теоретичари из Европске уније:

Вишејезичност је вештина коју је пожељно да поседују сви грађани Европе, она унапређује когнитивне вештине и јача вештине коришћења матерњег језика; омогућава нам да искористимо слободу да радимо и учимо у било којој Држави Чланици (ЕУ Бизнис 2008; истакле ауторке).

Проширујући овакву аргументацију, наводимо као веома корисно мишљење теоритичара Кука, који сматра да је употреба „два језика исто толико нормална, колико и употреба два плућна крила" (Кук 2002: 23). Процеси усвајања страног и матерњег језика не представљају два одвојена система, различита и неподударна. Напротив, истраживања показују да су сви језици у мозгу умрежени кроз вокабулар, синтаксу, фоноголију и прагматику на идентичан и међузависан начин, и да стога усвајање страног језика тече брже уколико се ослања на стабилну језичку структуру матерњег језика (Џеснер/Ценоз 2000: 252-260; Хауптман и др. 2008: 185-196).

Кључно питање код употребе матерњег језика по мишљењу Аткинскона остаје „права равнотежа” или одржив модел Л1, што није тако једноставно постићи. „Л1 може бити драгоцен ресурс ако се користи у одговарајућим временима и на одговрарајући начин" (Аткинсон, 1993: 2).

Што се тиче наших студената, сматрамо да су следеће језичке ситуације примерене у погледу употребе CJ:

1. Ради темељнијег разумењавања нових термина;

2. Ради додатног и прецизнијег појашњавања и давања инструкција;

3. Ради бржег усвајања вокабулара;

4. Ради пружања додатног осећаја сигурности у учењу; 
5. Ради богаћења и неговања самог матерњег језика;

6. Ради премошћавања социолошких и културолошких разлика; и

7. Ради квалитетнијег подвлачења сличности између језика и култура.

\section{4. СЛОЖЕНА РУДАРСКА ТЕРМИНОЛОГИЈА}

Када наставник језика одлучи да помогне студентима да науче рударске термине, он мора да укаже, пре свега, на когнитивну сложеност датог појма и лингвистичке тешкоће техничког жаргона које се врло често не могу свести на тражење и гледање еквивалената у двојезичном речнику. Прво, зато што на српском језику такви речници или не постоје уопште, или су великим делом недопуњени, застарели па самим тим и неупотребљиви. Друго, зато што се модерни глосари у електронском виду тек формирају, и њихова скромна база врло често је недовољна за потребе студената и професора језика. Посебну тежину у савременој рударској литератури на енглеском језику представља све већи број термина који се у ери експанзије рударског инжењерства свакодневно креира и непосредно у теорији и пракси примењује. Будући да се значење у нашем језику понекад потпуно другачије организује па тиме и преводи, од суштинског је значаја како ће се студенти снаћи у техникама превођења, имајући у виду да су данас најактивнији преводиоци рударске терминологије заправо сами инжењери и научници.

У наведеним примерима подељеним у три групе, може се приметити како се термини деле на: потпуно преведене на српски, делом преведене, а делом асимиловане речи, и коначно, све заступљенији начин, преузимање страних речи у целости са прилагођавањем изговора и евентуалним напуштањем фонетског правила о идентичном запису и изговору.

Табела 1. Потпуно преведене речи

\begin{tabular}{|l|l|}
\hline \multicolumn{1}{|c|}{ Енглески } & \multicolumn{1}{c|}{ Српски } \\
\hline bearing & лежиште, основа, носач, лежај \\
\hline compound- jaw crusher & ударна чељусна дробилица \\
\hline jig bed & постељица машине таложнице \\
\hline dense-medium washer & уређај за прање у тешкој средини \\
\hline dewatering-tank & резервоар за одводњавање \\
\hline
\end{tabular}


Табела 2. Делимично преведене речи

\begin{tabular}{|l|l|}
\hline \multicolumn{1}{|c|}{ Енглески } & \multicolumn{1}{c|}{ Српски } \\
\hline deep-cone thickener & dеeр-сопе згушњивач \\
\hline accretion ripple mark & акрецијски риплмарк \\
\hline emerged shoreline & емергентна обална линија \\
\hline single-bowl overshot & једностепени овершот \\
\hline turbidity flow & турбидитни ток \\
\hline
\end{tabular}

Табела 3. Потпуно усвојене стране речи

\begin{tabular}{|l|l|}
\hline \multicolumn{1}{|c|}{ Енглески } & \multicolumn{1}{c|}{ Српски } \\
\hline dragline & $\begin{array}{l}\text { дреглајн (у значењу типа багера који се користи за } \\
\text { откопавање и пребацивање материјала у откопани } \\
\text { простор) }\end{array}$ \\
\hline grader & $\begin{array}{l}\text { грејдер (у значењу машине за нивелисање или } \\
\text { равнање тераса) }\end{array}$ \\
\hline spigot & $\begin{array}{l}\text { спигот или спиготизам (систем цеви у облику чешља } \\
\text { преко кога се врши депоновање хидромешавине) }\end{array}$ \\
\hline NIMBY sindrom & $\begin{array}{l}\text { нимбизам (настао од: енгл. пот in mу bасkуагd, син- } \\
\text { дром означава отпор локалног становништва према } \\
\text { одеђеним интервенцијама и изградњи ризичних } \\
\text { објеката у околини, попут депонија, отпада итд.) }\end{array}$ \\
\hline cradle-to-grave system & $\begin{array}{l}\text { сradle-to-gravе систем (означава управљање опасним } \\
\text { отпадом од настанка до уклањања) }\end{array}$ \\
\hline
\end{tabular}

Наведени примери илуструју сложеност термина са којима се сусрећемо у савременом рударском инжењерству и преводилачку захтевност која се намеће пре свега језичком и доменском професору да тај термин на исправан начин преведе и пренесе студенту.

С друге стране, за студента је учење вокабулара и превођење нове терминологије динамичан процес који обухвата језичко и ванјезичко знање и који отвара бесконачно велики број преводилачких могућности и недоумица. Неадекватно усвојена терминологија за студента рударства може не само да омета тачност и течност говорног и писаног језика већ и да погубно утиче на његову будућу каријеру. Додатно отежавање у учењу представља низак ниво 
предзнања наших студената због слабог квалитета наставе унутар школе и ниског или ретког излагања енглеском изван школе.

Наша препоставка је да ће CLIL довести до бољих резултата у учењу у поређењу са традиционалним методама између осталог и због веће и боље могућности за увећање рецептивног вокабулара у складу са Крашеновом теоријом богатог инпута, као и тандемског и интегрисаног рада доменских и језичких предавача.

\section{5. ИСТРАЖИВАЮЕ, РЕЗУЛТАТИ И ДИСКУСИЈА}

Истраживање је спроведено са циљем да се испитају ставови студената по питању побољшања усвајања стручне рударске терминологије рационалном употребом матерњег (српског) језика, а у складу са основним начелима $C L I L$-а и Крашенове инпут хипотезе. Други део истраживања је везан за ефекте почетне фазе имплементације CLIL-a и стицања увида у предности педагогије интегрисаног учења.

Студентима је подељено 100 упитника у папирној верзији, од којих су 93 попуњена. Испитаници су били студенти прве године који су уписали рударство на Рударско-геолошком факултету 2015. год. Број часова енглеског језика је 4 сата недељно за 2 семестра, што износи око 130 сати наставе. Искази студената су оцењени на Ликертовој скали од пет могућих одговора: 1 - не слажем се, 2 - делимично се слажем, 3 - нисам сигуран, 4 - слажем се, 5 - у потпуности се слажем. Упитник је подељен на два дела.

- Први се односи на ставове студената према употреби СЈ у настави:

1. Сматрам да је употреба CJ неопходна за разумевање нових термина;

2. Сматрам да је употреба CJ неопходна у појашњавањима;

3. Сматрам да је употреба СJ корисна за осећај сигурности у учењу;

4. Сматрам да је употреба CJ корисна јер учим брже;

5. Сматрам да је употреба CJ корисна јер помаже проширењу матерњег језика. 
Слика 1. Ставови студената о употреби СЈ у настави

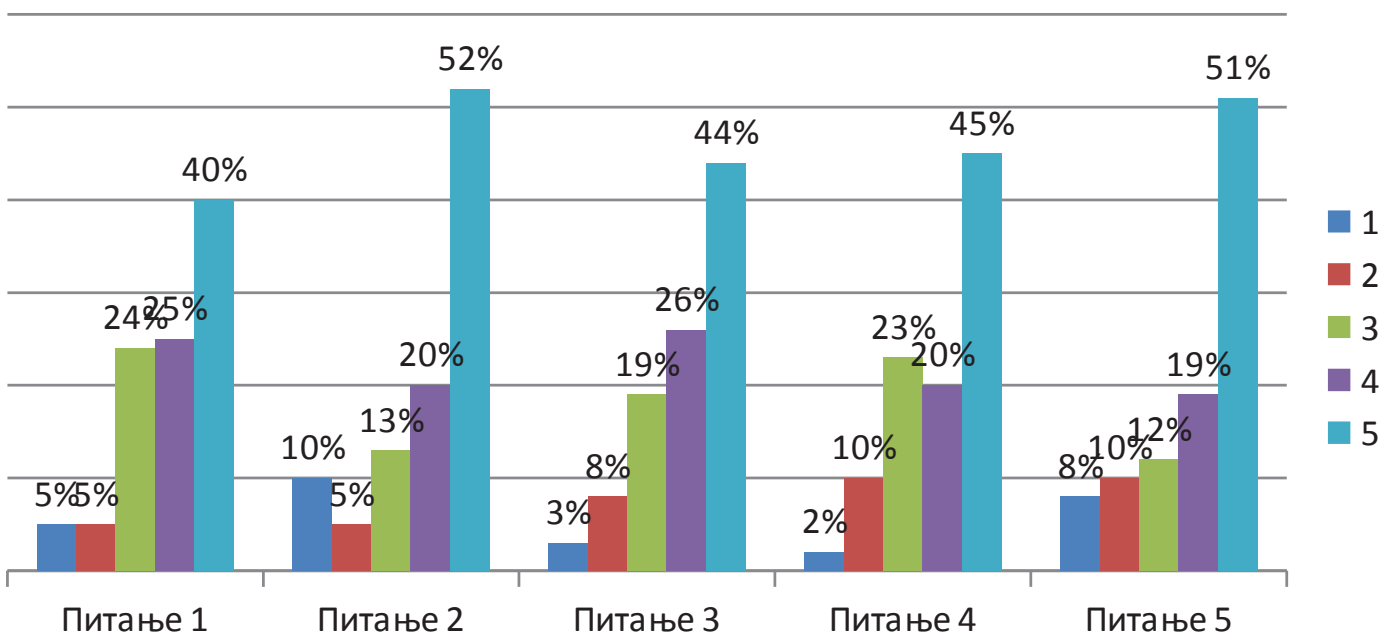

Питање 1: студенти су у великом броју (65\%) сагласни да је СJ неопходан за разумевање нових термина. Питање 2: готово две трећине студената (72\%) сматра да је СJ од пресудног значаја при појашњавању непознатог вокабулара. Питање 3: 60\% студената се слаже да им СЈ пружа осећај сигурности при учењу енглеског језика. Питање 4: резултати овог дела анкете указују да $65 \%$ учи брже уз СJ. Питање 5: студенти сматрају у великом проценту (60\%) да се уз страни језик видно богати и СJ.

- Други се односи на ставове студената према употреби CLIL методе:

1. Сматрам да је учење рударства путем CLIL методе занимљиво и корисно;

2. Сматрам да су садржаји CLIL наставе повезани са мојим потребама и интересовањима;

3. Захваљујући $C L I L-$ - имам бољу оцену из рударских студија;

4. Учење путем $C L I L$ методе ме охрабрује да више учим и говорим енглески језик;

5. $C L I L$ настава је у складу са реалним животом и мојим професионалним потребама. 
Слика 2. Ставови студената о употреби CLIL методе

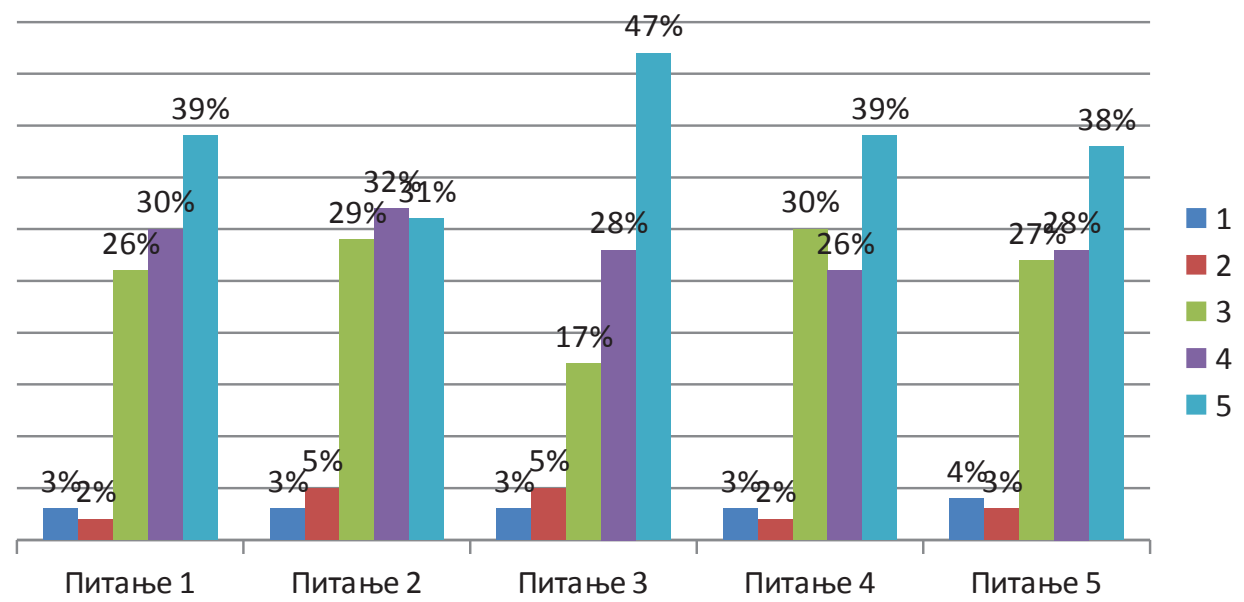

Што се другог дела анкете тиче, запажамо да су резултати били једнако задовољавајући. Питање 1: 69\% студената је дало високу оцену када је у питању квалитет наставе путем CLIL методе. Питање 2 : уочавамо корелацију са првим питањем, јер 63\% студената сматра да је $C L I L$ настава тесно повезана са њиховим конкретним потребама и интересовањима. Питање 3: по исказу студената чак $75 \%$ њих има бољу оцену из рударских студија захваљујући подстицају CLIL наставе. Питање 4: знатан број студената, њих 65\% је охрабрено да чешће говори и више учи енглески језик захваљујући $C L I L-y$. Питање 5: аутентични задаци и наставни материјали пробудили су интересовање студената и ка професионалним и реалним сферама живота, за шта се позитивно изјаснило $66 \%$ студената.

\section{6. ЗАКЉУЧАК}

Без претензија да у почетној фази можемо у потпуности испунити захтеве интегрисаног учења и досегнути захтевније моделе $C L I L$-a, на основу резултата нашег истраживања дошли смо до следећих задовољавајућих и охрабрујућих закључака:

Прво, подучавање енглеског језика уз помоћ CLIL-а представља нову, занимљиву и корисну педагогију која излази у сусрет потребама и интересовањима студената. Резултат тога је да учење престаје да буде пасиван процес и да студенти остварују боље резултате и на доменским и на лингвистичким проверама. Осим тога, студенти су охрабрени да усавршавају енглески језик у складу са својим реалним академским и каријерним потребама.

Друго, рад даје нови осрвт на питање о употреби СЈ, која у погледу сложене рударске терминологије као и у континууму учења језика и вокабулара добија афирмативну оцену. Употреба СJ није „издаја” учења страног 
језика, посебно тако амбициозно замишљеног као што је то CLIL приступ са великим бројем улаза у домен и језик (когнитивни, метакогнитивни, комуникативни и културолошки). Матерњи језик по моделу инпут хипотезе има супортивну улогу, он је средство побољшања језичке способности и СJ и ЕJ и представља незаобилазан пут у решавању недоумица, постизања прецизности, бољег разумевања и утврђивања разноврсне језичке употребе. Док су се некада теоретичари залагали за што мању употребу матерњег језика, или његово минимализовање у корист страног језика, овом студијом смо хтели да охрабримо рационалну и утемељену употребу CJ, персонализовану потребама самих студената.

Tpeће, усвајање вокабулара комбиновањем нове методе CLIL- $a$ и експлицитним приступом усвајања сложене рударске терминологије са нагласком на примену CJ, представља ефикасан, добро избалансиран приступ који ствара нове језичке навике којима се негују и ЕЈ и СЈ. Уводећи повишен фокус на реч или термин, како се он преводи и примењује, ојачавамо и проширујемо не само опште или специфично знање лексичности код студената, већ их припремамо за даље аутономно превођење, усвајање и стварање језичког амбијента који треба да обједини суштину и страног и матерњег језика и сачува вредности идентитета наших академских грађана.

\section{ЛИТЕРАТУРА}

Аткинсон 1993: D. Atkinson, Teaching monolingual classes. London: Longman.

Ayepбаx 1993: E. Auerbach. Reexamining English Only in the ESL Classroom. TESOL Quarterly, 27.

Блеклеш/Крис 2010: A. Blackledge \& A. Creese. Multilingualism: A critical perspective. London: Continuum.

Bexтер 2008: B. Wächter. Internationalization and the European Higher Education Area, report prepared for the official Bologna seminar of the Flemish government, Ghent, www.ond.vlaanderen.be/hogeronderwijs/bologna/BolognaSeminars/documents/Ghent/Ghent May 08 Bernd Waechter.pdf. [14.03.2017.]

ЕУ Бизнис: EU Business. A Guide to Languages in the European Union. http://www.eubusiness.com/topics/Languages/eu-languages-guide. 21.04.2017.

Каминс 2000: J. Cummins. Language, power and pedagogy: Bilingual children in the crossfire. Clevedon: Multilingual Matters. 
Колман 2006: J. A. Coleman,English-medium teaching in European higher education.Language Teaching, 39(01), 1-14.

Крашен 1985: S. D. Krashen, The input hypothesis: issues and implication. London: Longman.

Кук 2001: V. J. Cook, Using the First Language in the Classroom. http:// homepage.ntlworld.com/vivian.c/Writings/Papers/L1inClass.htm. [08.02.2017.]

Кук 2002: V. J. Cook, Portraits of the L2 user. Clevedon, England: Multilingual Matters.

Mapw 2002: D. Marsh, Content and Language Integrated Learning: The European Dimension - Action, Trends and Foresight Potential. In D. Marsh (Ed.). The European Dimension: Action, Trends and Foresight Potential. Public services Contract DG EAC. Strasbourg: European Commission.

Мохан 1986: B. Mohan, Language and Content. Reading: MA: Addison-Wesley.

Свејн 2000: M. Swain, The output hypothesis and beyond mediating acquisition through collaborative dialogue. In U. P. Lantolf(Ed.), Socio-cultural Theory and Second Language Learning. Oxford: Oxford University Press.

Свејн 2006: M. Swain, Languaging, agency and collaboration in advanced second language proficiency. In H. Byrnes (Ed.), Advanced Language Learning: Contribution of Halliday and Vigotsky. New York: Continuum.

Свејн и др. 2011: M. Swain et al., How to have a guilt-free life using Cantonese in the English class: A handbook for the English language teacher in Hong Kong. http://repository.ied.edu.hk/dspace/handle/2260.2/11955. [19.02.2017.]

Турнбул 2001: M. Turnbull, There is a role for the L1 in second language and foreign language teaching, but? The Canadian Modern Language Review. http://dx.doi.org/10.3138/cmlr.57.4.531. 17.03.2017.

Фернандез и др. 2008: D. J. Fernández, A. M. Armendáriz, R. Lothringer, L. Pico, L. Anglada, Proceedings Selection from XXXIII FAAPI Conference: Using the Language to Learn. Learning to Use the Language: What's next in Latin America. Santiago del Estero, Argentina: British Council.

Хауптман и др. 2008: S. Hauptman et al., A trilingual teaching model for developing academic literacy skills in classical Arabic (L1), Hebrew (L2) and English (FL) in southern Israel. Journal of Multilingual and 
Multicultural Development 29(3)<http://dx.doi.org/10.1080/01434 630802147601>. [07.04.2017.]

Џезнер/Сеноз 2000: U. Jessner and J. Cenoz, Expanding the Score: Sociolinguistic, psycholinguistic and education aspects of learning English as a third language in Europe. In J. Cenoz \& U. Jessner (Eds.), English in Europe: The acquisition of a third language. Clevedon, England: Multilingual Matters.

\section{TEACHING MINING TERMINOLOGY AT MGF USING THE $C L I L$ METHOD AND SERBIAN LANGUAGE IN THE FIRST YEAR OF STUDY}

\section{Summary}

The paper draws on the premise that the introduction of the CLIL method at FMG is useful and necessary as today's business, communication, science and research are strongly associated with the foreign language, that is, the English language (EL). In the initial intention to introduce the CLIL method into FMG in a sustainable way, we felt it necessary to help our students learn mining terminology by means of the Serbian language (SL) so that we could make it easier for them to form a quality linguistic foundation that could support them in their future content, cognitive, cultural and communicative development. Within this framework, in the paper we deal with: firstly, the characteristics of the CLIL method and the recommendations in vocabulary learning and teaching, secondly, insight into the complex mining terminology and how it is translated, and thirdly, the importance of the meaningful use of SL and its role in integrated learning. In the next part of the paper, we provided an empirical research that analyzes the perception of students about the offered learning model, while in the final part, the paper gives a positive argument about the usefulness of SL within the CLIL method and expresses a favorable attitude about the effectiveness of the offered model.

Key words: CLIL method, vocabulary teaching, mining terminology, EL, SL 